\title{
Load-Carrying Capacity Increase of Arch-Type Timber Roof
}

\author{
Janis Murnieks \\ department of Structural Engineering \\ Riga Technical University \\ Riga, Latvia \\ mure17@inbox.lv
}

\author{
Dmitrijs Serdjuks \\ department of Structural Engineering \\ Riga Technical University \\ Riga, Latvia \\ Dmitrijs.Serdjuks@rtu.lv
}

\author{
Karina Buka-Vaivade \\ department of Structural Engineering \\ Riga Technical University \\ Riga, Latvia \\ karina.buka.vaivade@gmail.com
}

\begin{abstract}
Possibility to increase load-carrying capacity of arch-type timber roof of multifunctional public building with the span equal to $60 \mathrm{~m}$ was analysed. Three-hinged segment arches with the rectangular glued cross-sections are considered as the main load-carrying structures in the transversal direction. Freely supported purlins with the massive rectangular cross-sections are considered as the main load-carrying structures in the longitudinal direction. The dependences between height of the arches, it bays and distances between the bracing members strengthening top and bottom zone of the arches cross-sections so as relative materials consumption and specific load-carrying capacity of the arches were obtained as the second power polynomial equations. Height of the arches and it bay changes within the limits from 10 to 30 and from 2 to $9 \mathrm{~m}$, correspondingly. The distances between the bracing members strengthening top and bottom zone of the arches changes within the limits from 2 till 10 and from 4 till $16 \mathrm{~m}$, correspondingly. The arch-type timber roof was considered under the action of the load combination which include structural dead weight, drifted and undrifted snow loads and wind loads. The relative materials consumption of the arches was determined as a relation between the dead weight of the arch to it span and changes within the limits from 24 till 114 $\mathrm{kg} / \mathrm{m}$. Glued and solid timber with strength classes GL24h and $\mathrm{C} 24$ are considered as materials of arches and purlins, correspondingly. The specific load-carrying capacity of the arches was determined as a relation between load-carrying capacity of the arche and volume of structural materials. Specific load-carrying capacity of the arches changes within the limits from 0.23 till $0.83 \mathrm{kN} / \mathrm{m} / \mathrm{t}$ in the case, if purlins are taken into account. It was shown, that the rational from the point of view of materials consumption and specific load-carrying capacity height of the arche, it bays so as the distances between the bracing members strengthening top and bottom zone of the arches are equal to $15,7.5,5$ and $15 \mathrm{~m}$, correspondingly. Corresponding values of relative materials consumption and specific load-carrying capacity are equal to 24 and $0.23 \mathrm{kN} / \mathrm{m} / \mathrm{t}$. The depth and width of the arche cross-section were equal to 1617 and $318 \mathrm{~mm}$, correspondingly.
\end{abstract}

It was shown, that strengthening of the arches crosssection by the steel bars of strength class $\mathrm{B500}$ and carbon fibre reinforced plastic tape Sika Crbo Dur S512 enables to increase load-carrying capacity of the arche by $\mathbf{1 0 . 2 0}$ and $9.48 \%$, correspondingly. But common use of the steel bars together with the carbon fibre reinforced plastic tapes enables to increase load-carrying capacity of the arche by $18.89 \%$.

Keywords-glued laminated timber, relative materials consumption, specific load-carrying capacity, three hinged segment arch.

\section{INTRODUCTION}

The problem of limited raw material and energy resources can be solved by decreasing the structural dead weight, increase of span and durability of load carrying structures so as by the replacement of non-renewable structural materials by renewable ones [1] - [3]. Production of the most widely used structural materials concrete and steel is responsible for from $5 \%$ to $8 \%$ of global greenhouse gas emissions and requires about $4 \%$ of global energy use [4]. Replacement of reinforced concrete and steel structures by the timber ones is one of the modern tendencies in civil engineering. Timber is a renewable structural material, which can be grown and as it grows, it consumes carbon. Timber structures are friendly for environment. Using of timber structures enables to decrease impact on the planet. Structural members from glued laminated timber and other timberbased materials are widely used for one-storey and multistorey buildings [4]. Timber as a structural material has a potential for substitution of concrete and steel in its major applications.

Arch-type timber structures take a special position among timber framework structures due to its shape and internal forces distribution in the major load-carrying members. Three-hinged arches are the most widely used static scheme for the long-span timber structures due to the increased compliance of timber in comparison with the steel and reinforced concrete. Sport stadium Majuro is an example of arch-type timber roof, where the main structures in the transversal direction are three hinged arches with span equal to $60 \mathrm{~m}$ (Fig.1.).

Two-hinged static schemes used for the structures with the short-spans in the case of glued cross-sections or for the long-span lattice arches [5] - [8]. Arch-type timber roof of Hakona hall is an example of the roof, where the main load-carrying structures in the transversal direction are lattice arches with the span equal to $86 \mathrm{~m}$ (Fig.1.).

So, framework of multifunctional residential building with three-hinged arches with the glued laminated rectangular cross-sections and span equal to $60 \mathrm{~m}$, was considered as an object of investigation. Using of the glued laminated timber cross-sections enables to increase 
fire resistance of the timber arches in comparison with the lattice ones [6]. Decrease of the structural dead weight enables to increase effectiveness of the structural solution for long-span structures [2]. Possibility to decrease structural dead weight and increase the loadcarrying capacity of arch-type timber roof is the aim of current investigation. The aim should be obtained by the evaluation of rational from the point of view of materials consumption geometrical parameters of the arch-type timber roof and by the increase of specific strength of the major load-carrying structural member's materials. Increase of the specific strength of the major loadcarrying structural member's materials can be obtained by strengthening of the arch's glued laminated rectangular cross-sections.

(a)

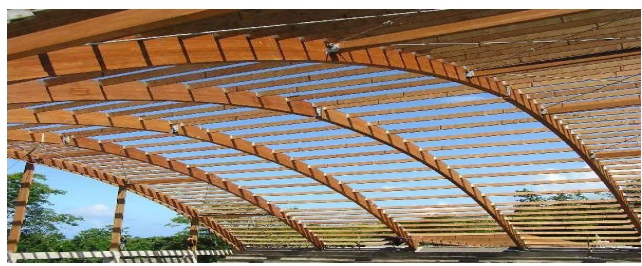

(b)

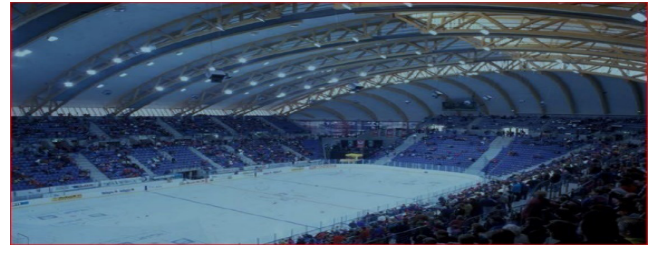

Fig. 1. Arch-type timber structures: (a) of sport stadium Majuro; (b) of Hakona hall [8].

\section{Approach to the SOlution of the PROBlem}

\section{A. Structural solution of the arch-type timber roof}

Framework of multifunctional residential building with three-hinged segment arches with the span and chamber equal to 60 and $10 \mathrm{~m}$, correspondingly, was considered as an object of investigation. Lateral stability of the arches so as overall stability of the timber framework was provided by the system of bracings including transversal bracings trusses so as the vertical bracings. Purlins, which are placed in the longitudinal direction, working as the loadcarrying members and bracing members at the same time (Fig. 2.).

Glued timber with strength class GL24h was considered as a material of glued rectangular arches cross-sections. Solid timber of strength class C24 was considered as a material of purlins and members of bracings.

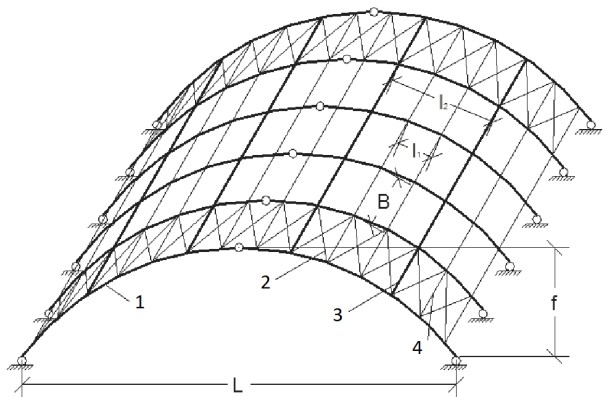

Fig. 2. Structural solution of considered arch-type timber roof: 1 - three-hinged arch; 2 - transversal bracing truss; 3 - vertical bracings; 4 - purlins; B - bay of arches; $1_{1}$ - distance between the purlins; $1_{2}$ - distance between the vertical bracings; $f$ - camber of arches; L - span of arches [8].

\section{B. Method of analysis}

Rational from the point of view of materials consumption height and bay of the arches so as bays of the bracing members providing lateral strengthening of the top and bottom parts of the arches cross-sections were determined for the arch-type timber roof. The response surface method and full factorial design were used to solve the problem. The numerical experiment of type $y=34$ was realised [9]. Where y is amount of the considered variants of the arch-type timber roof, 3 is amount of levels for each considered variable and 4 is amount of considered factors. So, the 81 variants of the arch-type timber roof were analysed. The height and bay of the arches so as bays of the bracing members providing lateral strengthening of the top and bottom parts of the arches cross-sections were considered as four variables and signed $\mathrm{f}, \mathrm{B}, 11$ and 12 , correspondingly. Relative materials consumption $(\mathrm{G})$ so as specific load-carrying capacity of the arches $\left(\mathrm{G}_{1}\right)$ were considered as parameters of optimization. The relative material consumption was considered as a relation of the structural dead weight to the span of the arch, measured in $\mathrm{kg} / \mathrm{m}$. The specific load-carrying capacity of the arches was found as a relation of load-carrying capacity of the arch to the total volume of all timber structures, measured in $\mathrm{kN} / \mathrm{m} / \mathrm{m}^{3}$.

All 81 variants of the arch-type timber roof were analysed by the using of software RFEM 5 at the action of permanent and variable loads (Fig.3.). Planar models for considered variants of the three-hinged arches were treated. The dimensioning and check of cross-sections of the arches, purlins and members of the bracings was carried out basing on the requirements of EN 1995-1-1. The arches, purlins and elements of the bracing system were considered as the members subjected to compression with the bending, flexure and axial loading, correspondingly. Lateral stability of the arches was checked by the formulas (1)-(2) in the case, if maximum normal stresses acting in the cross-section of the arch due to the bending moment are smaller, than the maximum normal stresses acting due to the compressive force [10], [11].

$$
\begin{aligned}
& \frac{\sigma_{c, 0, d}}{k_{c, z} f_{c, 0, d}}+k_{m} \frac{\sigma_{m, d}}{f_{m, d}} \leq 1 \\
& \frac{\sigma_{c, 0, d}}{k_{c, y} f_{c, 0, d}}+k_{m} \quad \frac{\sigma_{m, d}}{f_{m, d}} \leq 1
\end{aligned}
$$

Where: $\sigma_{m, d}$ and $\sigma_{c, 0, d}$ are maximum normal stresses acting in the cross-section of the arch due to the bending moment and compressive force, correspondingly; $f_{m, d}$ and $f_{c, 0, d}$ are the design resistances of timber in bending and compression, correspondingly; $k_{c, y}, k_{c, z}$ are factors, which should be determined by the equations (6.25) and (6.26); $\mathrm{km}$ is a factor, equal to 0.7 for rectangular sections.

Lateral stability of the arches was checked by the formula (3) in the case, if maximum normal stresses acting in the cross-section of the arch due to the bending moment are bigger, than the maximum normal stresses acting due to the compressive force [10], [11]. 


$$
\left(\frac{\sigma_{m, d}}{k_{c r i t} f_{m, d}}\right)^{2}+\frac{\sigma_{c, 0, d}}{k_{c, z} f_{c, 0, d}} \leq 1
$$

Where: $k_{\text {crit }}$ is a factor which takes into account the reduced bending strength due to lateral buckling; other designations as for formulas (1) and (2).

The dependences of relative materials consumption and specific load-carrying capacity of the arches on the height and bay of the arches so as bays of the bracing members providing lateral strengthening of the top and bottom parts of the arches cross-sections were obtained as the second power polynomial equations [9]. Equation (4) was written for the case, when relative materials consumption was considered as a parameter of optimization.

$$
\begin{aligned}
& G=b_{0}+b_{1} f+b_{2} B+b_{3} l_{1}+b_{4} l_{2}+b_{12} f B+ \\
& b_{13} f l_{1}+b_{14} f l_{2}+b_{23} B l_{1}+b_{24} B l_{2}+b_{34} l_{1} l_{2}+ \\
& b_{123} f B l_{1}+b_{134} f l_{1} l_{2}+b_{234} B l_{1} l_{2}+b_{124} f B l_{2}+ \\
& b_{1234} f B l_{1} l_{2}+b_{11} f^{2}+b_{22} B^{2}+b_{33} l_{1}{ }^{2}+b_{44} l_{2}{ }^{2}
\end{aligned}
$$

Where: $\mathrm{G}$ is relative materials consumption; $b_{i}, b_{i j}, b_{i j k}$ - coefficients; other designations are the same as in Fig. 3.

Equation for the case, when specific load-carrying capacity of the arches was considered as a parameter of optimization, has the similar form. Rational from the point of view of materials consumption height and bay of the arches so as bays of the bracing members providing lateral strengthening of the top and bottom parts of the arches cross-sections were determined for the arch-type timber roof by the system of equations (5):

$$
\begin{aligned}
& \frac{d Y}{d f}=b_{1}+b_{12} B+b_{13} l_{1}+b_{14} l_{2}+b_{123} B l_{1}+ \\
& +b_{134} l_{1} l_{2}+b_{124} B l_{2}+b_{1234} B l_{1} l_{2}+2 b_{11} f \\
& \frac{d Y}{d B}=b_{2} b_{12} f+b_{23} l_{1}+b_{24} l_{2}+b_{123} f l_{1}+ \\
& +b_{234} l_{1} l_{2}+b_{124} f l_{2}+b_{1234} f l_{1} l_{2}+2 b_{22} B \\
& \frac{d Y}{d l_{1}}=b_{3}+b_{13} f+b_{23} B+b_{34} l_{2}+b_{123} f B+ \\
& +b_{134} f l_{2}+b_{234} B l_{2}+b_{1234} f B l_{2}+2 b_{33} l_{1} \\
& \frac{d Y}{d l_{2}}=b_{4}+b_{14} f+b_{24} B+b_{34} l_{1}+b_{134} f l_{1}+ \\
& \quad+b_{234} B l_{1}+b_{124} f B+b_{1234} f B l_{1} 2 b_{44} l_{2}
\end{aligned}
$$

Where designations the same as for equation (4).

System of equations (5) was written for the case, when relative materials consumption was considered as a parameter of optimization. The obtained results then were analysed and corrected by the inspection.

\section{EVALUATION OF RATIONAL GEOMETRICAL PARAMETERS OF ARCH-TYPE TIMBER ROOF}

The segment three-hinged arches were considered under the action of permanent and imposed loads (Fig.3.). The permanent load includes dead weight of the roofing, elements of bracings and arches. Structure of roofing include corrugated steel sheets BALEX number TR50260 POSITIVE with thickness in $0.5 \mathrm{~mm}$, layer of heat insulation with thickness in $180 \mathrm{~mm}$, density in $140 \mathrm{~kg} / \mathrm{m} 3$ and layer of hydro isolation.

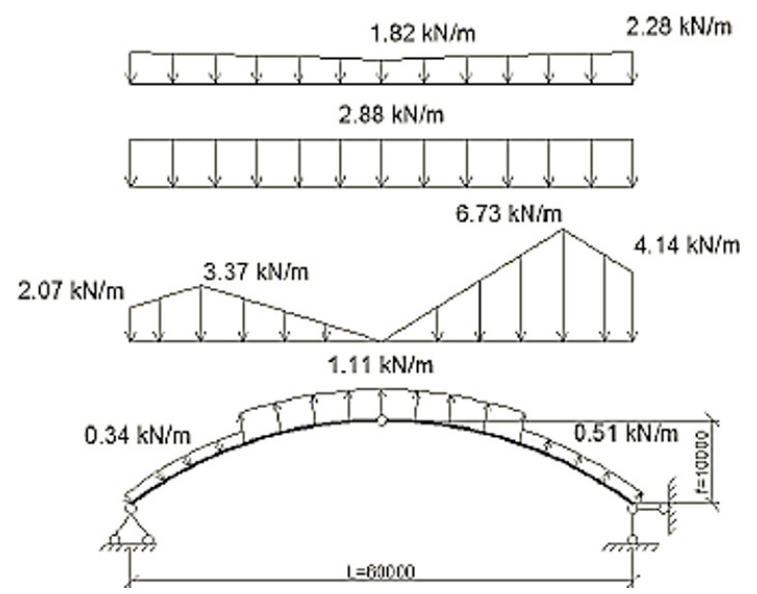

Fig. 3. Design scheme of three-hinged segment arche loaded by the permanent and imposed loads: a) - permanent load; b) - undrifted snow load; c) - drifted snow load; d) - wind load; The loads intensities are given for the bay of arches equal to $2 \mathrm{~m}$ [8].

Imposed loads are presented by the wind and snow ones. Permanent load has nonlinear distribution by the horizontal projection of the segment three-hinged arche and its intensity changes within the limits from 1.82 to $2.28 \mathrm{kN} / \mathrm{m}$. The snow and wind loads were determined for Riga climatic conditions [12]. The snow load includes two variants - undrifted snow load and drifted one. Intensity of undrifted snow load is equal to $2.88 \mathrm{kN} / \mathrm{m}$, but for drifted snow load it intensities changes within the limits from 2.07 to $6.73 \mathrm{kN} / \mathrm{m}$. Intensities of the wind load are equal to $0.34,1.11$ and $0.51 \mathrm{kN} / \mathrm{m}$ for zones $\mathrm{A}, \mathrm{B}$ and $\mathrm{C}$, correspondingly. The boundaries between zones A and $\mathrm{B}$ so as zones $\mathrm{B}$ and $\mathrm{C}$ is placed on the height $0.7 \mathrm{f}$, which is equal to $7 \mathrm{~m}$. The wind pressure in zones $\mathrm{B}$ and $\mathrm{C}$ is negative (Fig.3.).

The height and bay of the arches so as bays of the bracing members providing lateral strengthening of the top and bottom parts of the arches cross-sections changes within the limits from 10 to $30 \mathrm{~m}$, from 2 to 9 $\mathrm{m}$, from 2 to $10 \mathrm{~m}$ and from 4 to $16 \mathrm{~m}$, correspondingly. The dependences of relative materials consumption and specific load-carrying capacity of the arches on the height and bay of the arches so as bays of the bracing members providing lateral strengthening of the top and bottom parts of the arches cross-sections, are shown on Fig. 4 and 5, correspondingly.

(a)

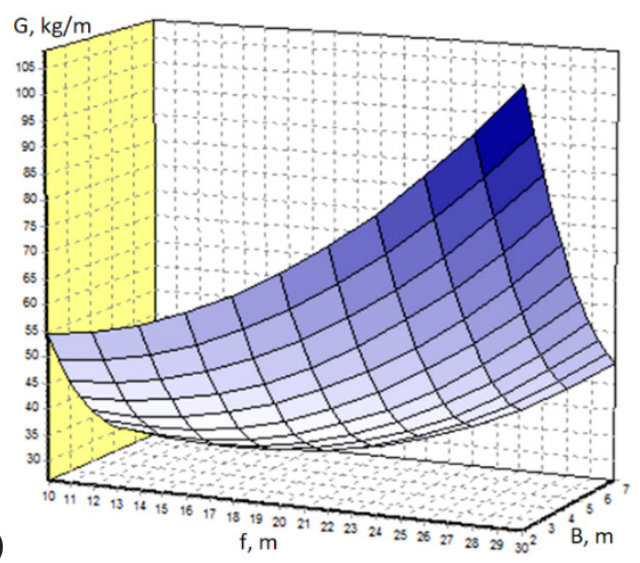


(b)

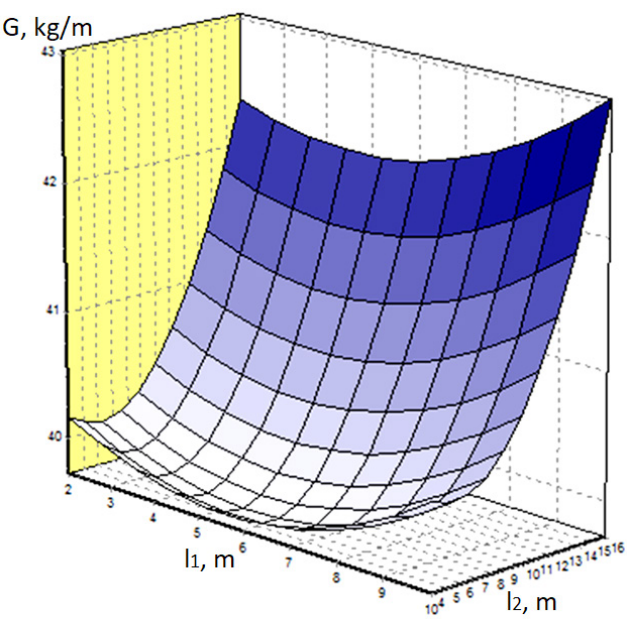

Fig. 4. The dependences of relative materials consumption (G): (a) as a function from the height (f) and bay (B) of the arches; (b) as a function from the bayes $\left(1_{1}\right)$ of the bracing members providing lateral strengthening of the top and bottom parts of the arches cross-sections $\left(1_{2}\right)$ [8], [13].

The relative materials consumption changes within the limits from 24 to $114 \mathrm{~kg} / \mathrm{m}$. The specific load-carrying capacity of the arches changes within the limits from 0.06 to $0.38 \mathrm{kN} / \mathrm{m} / \mathrm{m}^{3}$ at the same time.

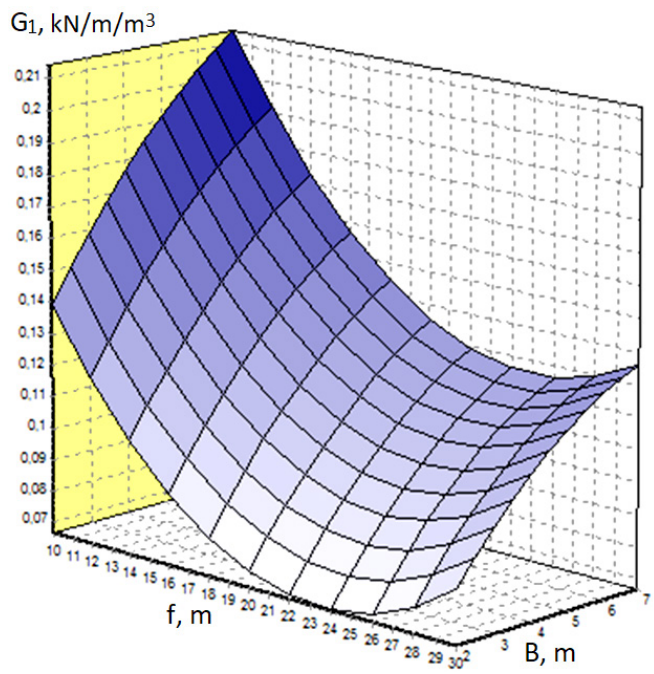

(a)

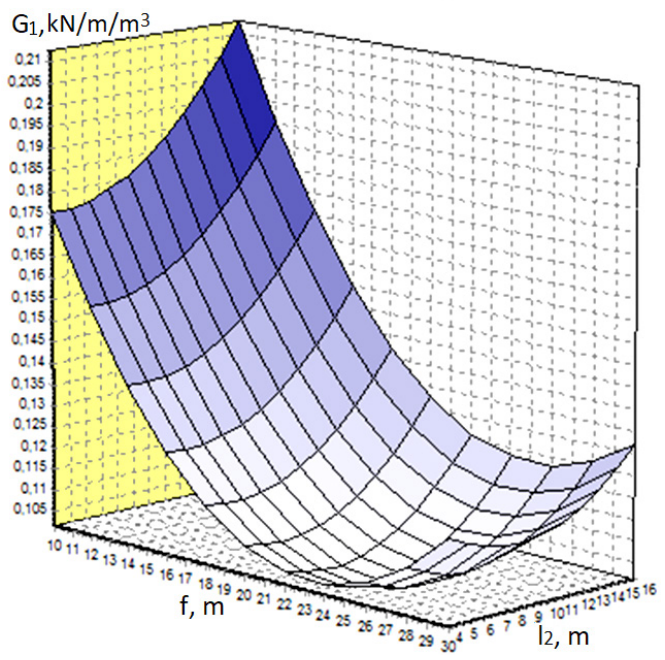

(b)

Fig. 5. The dependences of specific load-carrying capacity of the arches $\left(\mathrm{G}_{1}\right)$ (a) as a function from the height (f) and bay (B) of the arches; (b) as a function from the from the height (f) and bay of the bracing members providing lateral strengthening of the bottom parts of the arches cross-sections $\left(l_{2}\right)$ [8], [13]
The using software EdaOpt [13] obtained the dependences shown on the Fig. 4 and 5. It was stated, that the rational from the point of view of materials consumption and specific load-carrying capacity of the arches, it height and bay so as bays of the bracing members providing lateral strengthening of the top and bottom parts of the arches cross-sections are equal to $15,7,5,5$ and $15 \mathrm{~m}$, correspondingly. Corresponding values of relative materials consumption and specific load-carrying capacity of the arches are equal to $24 \mathrm{~kg} / \mathrm{m}$ and $0.38 \mathrm{kN} / \mathrm{m} / \mathrm{m}^{3}$. Three-hinged segment arch for the estimated best variant has glued laminated rectangular cross-section with depth and width equal to 1617 and $318 \mathrm{~mm}$, correspondingly.

\section{LOAD-CARRYING CAPACITY INCREASE OF ARCH-TYPE TIMBER ROOF}

Possibility to increase specific load-carrying capacity of the considered arch-type timber roof by the increase of specific strength of arches structural materials was analysed. Structural material of the arches was glued laminated timber with strength class GL24h. The increased specific strength was provided by cross-section strengthening by two steel bars with diameters in 22 $\mathrm{mm}$, placed both in the top and bottom zones of crosssection. The fibre reinforced plastic tapes with width and thicknesses equal to 150 and $1.4 \mathrm{~mm}$, correspondingly, placed in the top part of cross-section only. Steel of grade B500 with point of yielding in $420 \mathrm{MPa}$, was considered. The carbon fibre reinforced plastic tape Sika Crbo Dur S1514 so as glass fibre and aramid fibre reinforced plastic tapes with tensile strengths equal to 3100, 896 and 557 $\mathrm{MPa}$ were considered as the strengthening materials [8]. Transformed section method and software RFEM 5 was used for analysing of arch-type timber roof. The roof with the evaluated in the previous chapter rational from the point of view of materials consumption and specific load-carrying capacity of the arches, its height and bay so as bays of the bracing members providing lateral strengthening of the top and bottom parts of the arches, was considered under the action of permanent and drifted snow load. Specific load-carrying capacity increase for different variant of the arch cross-section strengthening is shown on Fig. 6.

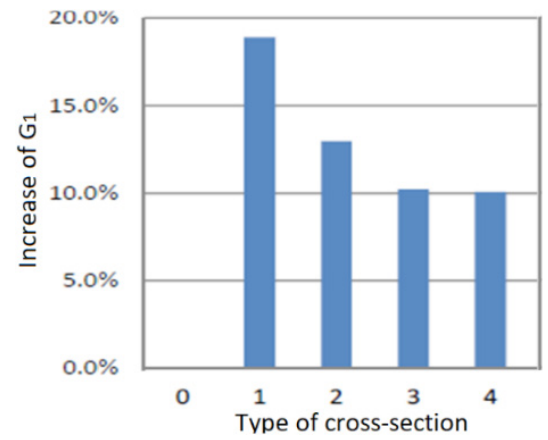


(b)

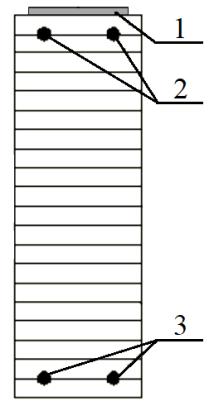

Fig. 6. $\mathrm{G}_{1}$ increase for different variant of the arch cross-section strengthening (a): 0 - without reinforcement; 1 - steel bars both in the top and bottom zones and carbon fibre reinforced plastic tape in the top zone; 2 - steel bars both in the top and bottom zones and glass fibre reinforced plastic tape in the top zone; 3 - steel bars both in the top and bottom zones and aramid fibre reinforced plastic tape in the top zone; 4 - steel bars both in the top and bottom zones. (b) reinforcement placement for variants 1, 2, and 3: 1 - fibre reinforced plastic tape; 2 - steel reinforcement in the top zone; 3 - steel reinforcement in the bottom zone [8].

It was stated that the maximum increase of specific load-carrying capacity of the arch-type timber roof was equal to $18.89 \%$. Specific load-carrying capacity grows from $0.38 \mathrm{kN} / \mathrm{m} / \mathrm{m}^{3}$ to $0.45 \mathrm{kN} / \mathrm{m} / \mathrm{m}^{3}$. It was obtained for the case, when the steel bars both in top and bottom zones strengthened the cross-section and the carbon fibre reinforced tape strengthened the bottom zone. But the specific load-carrying capacity of the arch-type timber roof grows by $10.20 \%$ when the cross-section of the arch was strengthened by the steel bars both in the top and bottom zones [8].

\section{Conclusions}

Rational from the point of view of materials consumption geometrical parameters of the arch-type timber roof with the span equal to $60 \mathrm{~m}$ were evaluated. It was stated, that the rational from the point of view of materials consumption and specific load-carrying capacity of the arches, its height and bay so as bays of the bracing members providing lateral strengthening of the top and bottom parts of the arches cross-sections are equal to 15 , 7,5, 5 and $15 \mathrm{~m}$, correspondingly. Corresponding values of relative materials consumption and specific loadcarrying capacity of the arches are equal to $24 \mathrm{~kg} / \mathrm{m}$ and $0.38 \mathrm{kN} / \mathrm{m} / \mathrm{m}^{3}$.

Possibility to increase load-carrying capacity for archtype timber roof was considered. It was stated, that specific load-carrying capacity of the arch grows by $18.89 \%$ in the case, when the steel bars both in top and bottom zones strengthened the cross-section of the arch and the carbon fibre reinforced tape strengthened top zone.

\section{ACKNOWLEDGMENTS}

The research leading to these results has received the funding from Riga Technical University, Faculty of Building and Civil Engineering Grant "DOK.BIF/18".

\section{REFERENCES}

[1] J. Suzuki, T. Mizukami, T. Naruse and Y. Araki, "Fire resistance of timber panel structures under standard fire exposure," Fire Technology, No. 52, pp. 1015-1034, 2016. DOI: 10.1007/s10694-016$0578-2$

[2] V. Goremikins, D. Serdjuks, K. Buka-Vaivade, L. Pakrastins, and N.I. Vatin, "Prediction of behaviour of prestressed suspension bridge with timber deck panels," The Baltic Journal of Road and Bridge Engineering, vol. 12(4), pp. 234-240, 2017. DOI:10.3846/ bjrbe.2017.29

[3] V. Goremikins, D. Serdjuks, K. Buka-Vaivade and L. Pakrastins, "Choice of rational structural solution for smart innovative suspension structure," In Proc. of the 3nd International Conference on Innovative Materials, Structures and Technologies, September 27-29, 2017, Riga, Latvia. IOP Conf. Series: Materials Science and Engineering, vol. 251, pp.1-8, 2017. DOI: 10.1088/1757$899 X / 251 / 1 / 012083$

[4] M. Green and J. Taggart, Tall Wood Buildings Design, Construction and Performance. Basel: Birkhauser, 2017. DOI:10.1080/24 751448.2018.1497379

[5] W. M. C. McKenzie and B. Zhang, Design of structural timber to Eurocode 5. London: Palgrave Macmillan, 2007, 508 p.

[6] T. Saknite, D. Serdjuks, V. Goremikins, L. Pakrastins and N.I. Vatin, "Fire Design of Arch-type Timber Roof," Magazine of Civil Engineering, vol. 64(4), pp. 26-39, 2016. DOI: 10.5862/MCE.64.3

[7] M.V. Gravit, E.V. Golub and S.P. Antonov, "Fire protective dry plaster composition for structures in hydrocarbon fire," Magazine of Civil Engineering, vol. 79(3), pp. 86-94, 2018. DOI: 10.18720/ MCE.79.9.

[8] J. Murnieks, "Analyse of load-carrying capacity increase for timber roof," M.S. thesis, Riga Technical university, Riga, Latvia, 2015.

[9] L. Eriksson, E. Johansson, N. Kettaneh-Wold, C. Wikström, and S. Wold, Design of Experiments: Principles and Applications, MKS Umetrics AB, 2008.

[10] Eurocode 5: Design of timber structures - Part 1-1: General Common rules and rules for buildings.

[11] J. Porteous and A. Kermani, Structural timber design to Eurocode 5. Malden, MA: Blackwell Publishing Ltd, 2007, 542 p.

[12] Eurocode 1: Actions on structures - Part 1-1: General actions Densities, self-weight, imposed loads for buildings Eurocode.

[13] J. Auzinsh, EdaOpt software user manual. Riga, 2007. 